Article

\title{
Grassland Governance and Common-Interest Communities
}

\author{
Anthony B. Schutz \\ University of Nebraska College of Law, University of Nebraska-Lincoln, P.O. Box 830902, \\ 215 McCollum Hall, Lincoln, NE 68583, USA; E-Mail: aschutz2@ unl.edu; \\ Tel.: +1-402-472-1248; Fax: +1-402-472-5185.
}

Received: 24 June 2010; in revised form: 13 July 2010 / Accepted: 13 July 2010 /

Published: 21 July 2010

\begin{abstract}
In the United States, today's ranches are engaging in small-scale nature-based endeavors to diversify their income base. But the geographic boundary of the land they own creates a relatively small area within which to operate, and fragmented ownership diminishes the ability of any single landowner to produce nature-based income. Collective action among nearby landowners can produce a set of resources from which all members of the group can profit. Such action can enhance the economic, social, and environmental sustainability of grasslands and the populations that use them. This article shows that common-interest communities can be used to provide and allocate wildlife and other resources on ranchlands, enabling individual landowners to generate more income from selling nature-based experiences to customers. Common-interest communities are familiar in urban settings but they have not yet been used in this setting. Thus, the article proposes a new approach to ranchland management based upon a familiar set of largely private legal arrangements. More broadly, the article illustrates the relevance of private law and private property to sustainable development by explaining how property owners can use private law to engage in environmentally beneficial and economically profitable enterprises on the vast privately owned landscape of the U.S. Great Plains.
\end{abstract}

Keywords: common-interest communities; collective action; law; rural development; servitudes; natural resources; wildlife 


\section{Introduction}

Cattle are not the only income source for today's ranches. One important alternative or supplemental source of income is the consumer who is willing to pay for access to places that offer nature-based recreational activities such as hunting, wildlife viewing, hiking, or the solace that comes from spending time on America's grasslands. Consumer demand for these sorts of opportunities can hardly be argued [1]. The interests that lobby for various laws governing the use and protection of natural resources are comprised of people who care about these resources-people who are likely willing to pay to enjoy them. People also spend a great deal of money travelling to our public lands. Even conservation research and education centers produce substantial economic benefits from consumers taking part in their activities, as Edwards and Thompson have recently found [2]. Leases for hunting access are also evidence of consumer demand in areas of the midwest [3]. However, consumer demand for nature-based activities remains a largely untapped source of income on the Northern Great Plains' privately owned grasslands.

From a conservation perspective, privately owned lands are tremendously important. As Morrisette explains [4] (p. 374),

There are few intact ecosystems today that exist solely on public lands. And yet, in some cases there are still remarkably intact ecosystems that exist almost exclusively on private lands. One-quarter of all ecosystem types are inadequately represented on federal lands, and seven percent are not found on federal lands at all. Most of the wetlands in the contiguous United States are privately owned. Approximately half of all threatened and endangered species in the United States are found exclusively on private lands, and 20 percent of the remainder spends half of their time on private lands.

The Northern Great Plains includes parts of Nebraska, South Dakota, North Dakota, Wyoming and Montana in the United States and parts of the Canadian provinces of Saskatchewan and Alberta [5]. Spanning approximately 723,000 square kilometers, only $2 \%$ of the region consists of public lands managed primarily for biodiversity conservation, while $76 \%$ of the land is in private ownership and approximately $64 \%$ of the privately owned land is devoted to livestock grazing [5].

A great deal of the land used for grazing is currently in its native or semi-native habitat; thus, it is one of the few areas in the world where there is an opportunity to conserve a grassland ecosystem at a large scale. The area is so important that the World Wildlife Fund has designated it as a "Global 200 ecoregion - one of the 238 most biologically significant places on Earth" [6] (p. 19). Most of the native grassland consists of mixed-grass or shortgrass prairie. As Edwards describes (p. 5), "While estimates differ, it appears that in the northern Great Plains only about $1 \%$ to $3 \%$ of the original tallgrass prairie remains intact, perhaps $20 \%$ to $30 \%$ of the mixed-grass prairie, and $40 \%$ to $70 \%$ of the shortgrass prairie" [7]. And while this ecoregion may lack the grandeur of the land to its mountainous west, it is spectacular upon closer examination. As Davidson explains (pp. 1, 21), "Prairie is one of the most subtle and complex of ecosystems, and to those who have taken the time to get to know it, there is nothing comparable. What to the untrained eye may seem to be a simple monoculture is in fact one of our most diverse sources of plant, soil, insect and animal life" [8]. 
The need for conservation on the Northern Great Plains is pressing. Its privately owned grasslands are being converted to cropland at an increasing pace due to high commodity prices (attributable to a variety of factors like biofuels policy) [8] and government programs [6] (p. 54). Livestock production can also cause significant damage to the biodiversity of the region. Traditional grazing practices are not suited to certain grassland bird species, and grazing in riparian areas results in degradation. In addition, native grazers like prairie dogs and elk are eliminated or their populations capped in favor of cattle production, and large carnivores are largely missing from the landscape [6] (pp. 58-59). On these lands, wildlife is eliminated or managed as a pest to be reluctantly tolerated. It is not often viewed as a valuable resource.

Although the landscape is important and the need pressing, implementing conservation policy on the Northern Great Plains is difficult. Producers often decry conservationist interference with their operations by claiming that producers are the best stewards of the land. But history shows that producers are unlikely to produce the ecosystem goods and services that we need to ensure a healthy and prosperous future. Indeed, if we are entitled to those goods and services, these stewards are not merely reluctant providers; they are causing a great deal of harm [9-11]. Non-point source pollution and nutrient loading in our nation's waterways is but one example of environmental damage that undercuts producers' stewardship claim.

The stewardship claim is not, however, unfounded. Farmers and ranchers have a deep love for the landscape they have toiled on and against for so many generations; they rely upon biological processes for their livelihoods; and almost all maintain that they want to give it to their children. Moreover, our understanding of production agriculture's environmental consequences grows as time goes on, so informational deficiencies may be partly responsible for producers' shortcomings. However, one key problem remains: the biological processes from which producers profit have been narrowly defined by the markets they serve. Thus, producers' management choices respect nature to the extent it makes economic sense. Protecting downstream water quality creates no income for producers. Carbon storage has made no money, until recently. And, importantly for my purposes, habitat and biodiversity losses are not lost opportunities but gains in productive capacity.

However, times are changing. Ecological services markets are emerging as a preferred policy choice for maintaining or enhancing the environmental benefits that flow from privately owned lands, including farms and ranchlands [12-15]. Using consumer demand for nature-based activities is another market-based means of attaining environmental ends. If managed differently, this ecoregion could support diverse and flourishing populations of vegetation and animal life. In its current state, the land is managed primarily for cattle because ranching is the owners' main source of income. But if a rancher could make his or her ranchlands more multifunctional, he or she could charge consumers for access to nature-based activities. Such an enterprise would, in turn, add value to wildlife and the other resources that consumers will pay to experience. That increased profitability would help stem the current tide of high commodity prices and sodbusting, while helping alleviate some of the environmental consequences of grazing. Thus, conservation on the privately owned landscape of the Northern Great Plains may be as much about rural development as it is about environmentalism.

The notion of finding a beneficial correlation between environmental benefits and rural development is not new. Rural development proponents have often touted agri-tourism, eco-tourism, or simply tourism as a piece in the puzzle of maintaining a vibrant rural economy $[16,17]$. Sometimes, 
however, producers do not embrace this notion of rural development because they view themselves as food, fiber, and fuel producers. They may not feel that they and their ancestors endured a great many difficulties - settling the American West, the Dust Bowl, cyclical farm crises, and many other personal hardships - to provide a tourist experience. They may believe they have a higher calling: feeding the world. But given rural population loss, fluctuating income, and the absence of opportunities for adult family members to stay on or return to the ranch, the general desire to maintain business as usual may fade in favor of non-traditional income opportunities [18].

Signs of nature-based entrepreneurship are emerging, even in areas where policy makers have not intervened to create markets. The Switzer Ranch [19] operation, near Burwell, Nebraska, is one example of multi-functionality driven by consumer demand. The Switzer family began diversifying its ranch in 2001 by building lodging for guests and offering horseback riding, guided hunting, bird watching, and boating services on a nearby river. The family formed Calamus Outfitters [20] as a way of marketing these new endeavors. Today, Calamus Outfitters offers a wide range of experiences for the paying customer seeking to experience the beauty of Nebraska's Sandhills region, including its flora, fauna, wildlife, and ranching heritage. Importantly, the Switzers continue to raise cattle, which belies any rigid dichotomy between conservation and production [21].

Internationally, privately owned areas that are devoted to nature-based tourism and recreation have already emerged as a viable means of nature conservation [22]. While such efforts are relatively new to the grasslands of the United States, places like Namibia, Kenya, Botswana, Venezuela, and Brazil have working examples of nature-based entrepreneurship on their privately owned lands [21,23-28].

Non-governmental organizations are also recognizing the link between conservation and rural development. The World Wildlife Fund is one example [18], and it has proposed standards for privately owned conservation land [5].

As elsewhere, there are challenges confronting nature-based entrepreneurs on the Northern Great Plains. In order for ranchers to provide unique opportunities - opportunities above and beyond what one already finds in an environment managed predominantly for agricultural production-geographic size is critical [7]. Ranchers with relatively small tracts of land may be unable to offer much, if anything, unique. The acquisition of more land is an option. However, there are a variety of reasons for exploring other options, not the least of which is to avoid concentrated land holdings on our rural landscapes. In fact, the preservation of prosperous rural populations may require a different option [29].

The Switzers have encountered the size problem. Wildlife provide the foundation for parts of their business. The presence of wildlife depends on how the grassland is managed at a large scale. If the Switzers' grassland-management choices extended beyond the reach of their 12,000 acre property, wildlife populations could rise and become more diverse. Access to neighboring lands would also open up more opportunities for hunting, camping, bird watching, and other land-based activities. To that end, the Switzers have sought the cooperation of neighbors to enhance the presence of wildlife on their and their neighbors' ranches, offering their customers a geographically and ecologically broader experience. Environmentalist organizations have noticed the benefits of the Switzers' effort. Recently, the Audubon Society designated the Switzers' property along with cooperating neighbors' property as an Important Bird Area called the Greater Gracie Creek Landscape. It is the first privately owned site in Nebraska so designated [30]. 
Lawyers and the legal academy have not offered a discussion of the legal tools that would enable people like the Switzers to work across property boundaries with willing neighbors. This article starts to fill that void. It also contributes to the literature concerning how private law and private property can be used to tap consumer demand for recreational opportunities on the Northern Great Plains. Operating from a baseline of fee simple property ownership, landowners can reorder the rights they have within a sufficiently large geographic area to promote biological diversity and enhance their ability to partake of this income stream. As this article explains, the "common-interest community" is a possibility for collective action. While most commonly found in urban areas as a means of creating and selling communities within cities, these associations have attributes that may help deal with some of the challenges facing ranch owners.

This article is structured as follows. Section 2 contains a general discussion of the challenges facing nature-based entrepreneurs in ranch country. Section 3 contains an extended discussion of the legal options available for meeting these challenges, with primary emphasis placed on utilizing a common-interest community.

\section{Challenges}

This section provides the context necessary for understanding the need for the approach described in Section 3. It first discusses some of the challenges facing landowners who seek to profit from nature-based activities on their properties, showing that many of those challenges are collective action problems involving resources that are or would be common among neighboring landowners (2.1). As collective action problems involving common resources, the challenges landowners face can be thought of as provisioning and allocation problems, which are discussed next (2.2). Often provisioning and allocation problems can be solved by creating a collaborative institution. Effective and long-enduring institutions for collective action often exhibit certain fundamental traits, which I set forth at the end of this section (2.3). Section 3 describes how collective action can be ordered to deal with provisioning and allocation problems through a mechanism for collective action called a common-interest community.

\subsection{Challenges Facing Nature-Based Entrepreneurs}

There are three primary challenges to nature-based entrepreneurial efforts on ranchlands: entrepreneurial risk, operational difficulties, and geographic size. The first challenge arises from the entrepreneurial nature of these enterprises. The return that ranchers are likely to receive from their efforts is inherently uncertain at this point. With active commodity markets, ranchers can make investments with some idea of what the likely return will be and the time horizon associated with it. But the return from providing the sorts of opportunities described in this article is less well known.

This challenge is largely beyond private law's purview. That is, landowners cannot solve these problems through any particular legal arrangement among themselves. Government or NGOs could help deal with this problem by subsidizing this new sort of production or buying the output but landowners cannot avoid this risk through collective action. Nonetheless, this uncertainty should inform the legal arrangement. For example, flexibility should be built into these sorts of ventures so that they can be undone if things do not pan out. 
The second primary challenge is operational. Managing land for its landscape or wildlife value is a new concept to many landowners, and it involves complex questions of conservation biology [31]. Many landowners may not be experts in managing their lands to produce the sorts of ecological goods and services that will ultimately attract paying customers. Further, a particular practice may take years to pay dividends, and certain practices-for instance controlled burning on unstable soils-may necessitate land retirement for an entire grazing season. Without a viable means of dealing with these problems, landowners may be unwilling to enter this market.

These problems can be met to some extent through collective action. By joining together, ranches may be able to share the costs associated with new management practices, delayed returns, and developing or hiring the necessary expertise. Public land-grant universities or NGOs can also develop and disseminate information necessary for this sort of production.

The third and most salient challenge facing landowners is the geography of property or, more specifically, the physical boundaries associated with land ownership. This boundary problem is common to ecosystem governance in general [32]. For instance, with governmental approaches to solving environmental and natural resources problems, the lines we draw on landscapes in the form of political boundaries are problematic when a problem transcends those boundaries. So-called cross-border collaboration among governmental entities is thus a common subject in the public sector [33]. The issue also arises in the private sector, where the relevant lines are property boundaries [32]. Depending upon the opportunity that the rancher would like to sell, a large amount of land may be necessary. For instance, managing a habitat for a sizeable herd of large mammals takes a large amount of land to accommodate their home range. Most individual ranchers will not have enough. For species with habitat needs that do not necessarily cross property boundaries, expanding the geographic size of the operation is likely to increase diversity simply as a function of including a more diverse array of habitat types. Thus, to the extent income increases with diversity and the presence of large mammals, bigger is better.

Ecological and efficiency scales can also ensue from getting bigger [34] (p. 80). As Elmendorf states (p. 549), "The ecological benefits of a given form of investment increase more than proportionately with the number of contiguous acres subject to treatment" [35]. If income increases with ecological benefits, bigger is again better. And larger size opens up the possibility of allowing or replicating ecological processes that are impossible or less effective at small scales, like prairie fires or the grazing pattern of a herd of wild ungulates [5] (p. 76).

Producers are also reluctant to invest in the production of ecological goods and services within a limited geographic area because the benefits of their investments may spill beyond their boundaries [34] (p. 80). Habitat creation and management is, again, an example. If an investment in habitat is made (e.g., by constructing new facilities or changing one's grazing practices), neighboring landowners may reap some of the benefits of increased wildlife populations while sharing none of the costs of increasing that population. These extra-territorial benefits do not generate a return so long as they remain extra-territorial. A landowner will only invest in activities that produce a return on his own land. Again, expanding the territory involved helps deal with this problem. Of course, some spillover is likely to remain. The challenge is to expand the territory to a level where the intra-territorial benefits generate a sufficient return. 
This territorial-benefits problem is related to two sorts of participation problems - hold outs and defectors. At the start of an operation, the prospect of free-riding provides an incentive to hold out [34] (p. 76). If a landowner can get the benefits without incurring any of the costs of joining, it is unlikely he will join. If that is the case, and if that landowner is necessary to the collective effort, then the project does not materialize. In this article, I assume a group of ranchers wishes to cooperate, so I largely assume the absence of holdouts. Even on that assumption, however, an incentive to defect arises among cooperating landowners. Any landowner may decide to defect, ending his or her participation to take advantage of the established practices in the short run without making contributions that would serve the long-term interests of the group.

Fortunately, we have existing legal tools to deal with problems related to geographic size. Many landowners typically see this problem as one that can be solved only by acquiring more land, and high land costs can keep many out of this line of business. However, land acquisition is not necessary. It would be, of course, if a landowner needed to acquire the complete set of rights we bundle into the concept of property ownership. But landowners seeking to engage in nature-based entrepreneurial activities on their own land need only a few of the rights associated with the neighbor's property. They do not, for instance, need the right to occupy the neighbor's property to grow crops or live in a dwelling. Rather, they need only those rights that are necessary to their endeavor. For example, in order to produce and maintain an increased presence of wildlife, an individual needs a method for ensuring that management practices on nearby lands are adapted to provide suitable habitat and assurances that this will continue for a sufficient period of time. Given property's typical geography, the owner's own management choices are insufficient to create the resource and the owner has no ability to make management decisions on the neighbor's land. Thus, the landowner needs a portion - but only a portion - of the neighbor's property rights. And the neighbor needs a portion of his property rights if he also wishes to create the wildlife resource.

This limited exchange of property rights holds the promise of joint gain, allowing cooperating landowners to create together what neither of them can accomplish on their own. Once they have overcome the physical boundaries between their properties, cooperating landowners can also achieve greater ecological benefits at a lower cost within a larger territory, and they are more assured that their investment returns will materialize within their collective boundaries.

However, even if landowners can overcome territorial boundaries for management purposes, property boundaries still cause problems. For instance, if all of the benefits of a joint effort were to materialize on one property owner's property, the resulting inequity could ruin the cooperative effort. Thus, a further portion of the landowners' property rights can be exchanged-one that gives each landowner limited access to the other's property to capitalize on the wildlife resource they have created.

The effort at collective action can also be marred by individual activities that damage the availability or value of the resources for other cooperating landowners. And the problem of defection looms. Thus, further rights and obligations need to be crafted.

\subsection{Provisioning \& Allocation}

Cooperating landowners face collective action problems involving the creation and use of common pool resources-resources common as to group members but from which the group can exclude 
non-members. Ostrom's two categories of issues facing collective action are helpful in thinking about the problems facing landowners in this context. Her categories consist of (1) provisioning problems and (2) allocation problems [36]. With provisioning problems, the main concern is the production of the resources that the individuals within a group will use. Allocation problems arise when multiple parties carry on activities that use the resources available to group members in common. Thus, allocation issues center on managing use to guard against harming the resources being allocated.

Provisioning problems initially involve a choice about what exactly the group wants to produce together. Landowners must answer a fairly simple question: "What can we do together that we are unable to do on our own?" The clearest candidate for provisioning is wildlife. Cooperation is necessary primarily where an individual cannot effectively provision adequate wildlife resources within his or her own boundaries. Thus, all willing participants must contribute to its production by collectively managing their land to provide a habitat suitable to the species or array of species they seek to provision. Those cooperating landowners will also need a means of determining who will bear what provisioning costs.

Allocation problems arise after the common resource is created. The most apparent allocation problems are associated with the wildlife resource and relate to maintaining the resource base in the face of consumption. As I discuss below (3.3) many states allocate the consumption of certain species through hunting laws. Such laws play a key role in maintaining the wildlife population. However, in some instances, the state's allocation determinations may not be made with the geographic boundaries of the cooperating landowners in mind. Thus, for instance, a group of cooperating landowners that successfully attracts hunters with state-issued permits may face the prospect of over-consuming the local resource base without harming the resource base of a larger region. If that is the case, the parties will need to determine how many animals of a given species can be hunted without harming the local population, despite the state's role in allocation. And, of course, if the state plays no allocation role with regard to hunting a particular species, then the parties will bear full responsibility for allocation. In addition, regardless of the state's role in allocating consumption to maintain species' populations, the parties will need to determine how hunting opportunities will be distributed among the cooperating owners. And they will need to determine whether and under what conditions landowners may access each other's property for hunting. Given the mobility of the resource base, limiting each participant to hunting on his own land may prove inadequate.

The mobility of the resource base poses other allocation problems as well. Not all uses of the wildlife resource will involve consumption. For example hiking, camping, and horseback riding experiences may be more valuable when wildlife is present. If wildlife appear on some properties and not others, access for these activities is something that should be allocated among the parties who created the wildlife resource. In addition, such an allocation must take care to avoid damage to the resource. Thus, the parties may want to control overcrowding at campgrounds or on trails.

Wildlife aside, nature-based activities like hiking, camping, and horseback riding can also raise provisioning and allocation problems. The first question facing the parties will be whether or not they want to cooperate to create a common resource, like a cross-boundary trail or campground open to other participants. If they do not need the cooperation of neighbors to create the resource, then neither provisioning nor allocation problems arise. But they may need to cooperate in those instances where 
no landowner can create the resource on his own or where the landowners can create a better resource by cooperating. For instance, cooperation on large landscapes with regard to these activities could enable the parties to create better trails, campsites in optimal locations relative to trails or infrastructure, and aesthetically pleasing landscapes. If this is something the landowners create through cooperation, they will have to deal with problems like determining who will bear what costs in creating and maintaining these shared resources (a provisioning problem) and how each party will be allocated access to this resource to avoid diminishing its value (an allocation problem).

\subsection{Institutional Design}

People often solve provisioning and allocation problems through institutional arrangements, and there is a growing body of work evaluating successful collective-action institutions. As I explain below, the common-interest community is, in essence, an institution that can be used to solve the provisioning and allocation problems that arise in this dynamic context. Thus, considering this work is important to thinking about how a common-interest community might be constructed. Ostrom has identified [36] (p. 90) [37] (p. 259) eight design principles that exist in many long-enduring self-initiated institutions for collective action among relatively small groups of individuals:

1. Clearly defined boundaries. The boundaries of the resource system (e.g., irrigation system or fishery) and the individuals or households with rights to harvest resource units are clearly defined.

2. Proportional equivalence between benefits and costs. Rules specifying the amount of resource products that a user is allocated are related to local conditions and to rules requiring labor, materials, and/or money inputs.

3. Collective-choice arrangement. Many of the individuals affected by harvesting and protection rules are included in the group who can modify these rules.

4. Monitoring. Monitors, who actively audit biophysical conditions and user behavior, are at least partially accountable to the users and/or are the users themselves.

5. Graduated sanctions. Users who violate rules-in-use are likely to receive graduated sanctions (depending on the seriousness and context of the offense) from other users, from officials accountable to these users, or from both.

6. Conflict-resolution mechanism. Users and their officials have rapid access to low-cost, local arenas to resolve conflict among users or between users and officials.

7. Minimal recognition of rights to organize. The rights of users to devise their own institutions are not challenged by external governmental authorities, and users have long-term tenure rights to the resource.

Ostrom's eighth design principle - that multiple layers of nested enterprises be responsible for appropriation, provisioning, monitoring, enforcement, conflict resolution and governance activities-is most often observed in large complex systems. I therefore omit this principle from the following discussion, but it should be noted that a layered or federal structure may emerge as necessary if a collective effort grows to a large enough size or if there is a need for coordination among many groups of cooperating landowners. Below, I consider the legal options for solving provisioning and 
allocation problems and constructing institutions that meet the first seven criteria, focusing mainly on common-interest communities.

\section{Legal Arrangements}

The legal options for dealing with these issues exist in a spectrum. Below, I describe the ends of the spectrum in general terms (3.1) to place the primary focus of this paper-the tools available for legally formalized landowner-initiated governance regimes - in context. From there, I settle on property law as a tool to analyze collective action in the grasslands context and explain how the common-interest community could deal with the provisioning and allocation problems identified above through an institution that meets Ostrom's design principles (3.2). This section ends with brief discussions of possible legal reforms (3.3), additional roles for common-interest associations on grasslands (3.4), the distinctions between common-interest communities and land trust arrangements (3.5), and the utility of formalized private-law arrangements in this area (3.6).

\subsection{The Legal Landscape}

The spectrum for dealing with provisioning and allocation problems runs from purely informal arrangements among groups of landowners on one end to governmental involvement on the other. In purely informal arrangements, landowners as a matter of custom manage their lands for the presence of wildlife and allocate access for hunting, open lands for camping, and so on. Such customs may extend to both provisioning and allocation problems. However, in such a setting there is no formal means (e.g., resort to the courts) to enforce the land management regime or govern individual uses of the resources. This is not to say that such efforts are ineffective. Rather, they may be highly effective within a community with strong social ties $[38,39]$. And one would expect to find Ostrom's traits among such effective institutions.

At the other end of the spectrum is governmental involvement. Government-which represents the collective will of a particular geographic area - can utilize its lands to provision wildlife and open its lands to users. On privately owned lands, governmental involvement can involve regulations that require owners to provision wildlife and open their lands to others, subject to constitutional limitations requiring compensation to landowners in some instances. Government can also control the allocation of resources through permit requirements, controls on the size of campgrounds, land use regulations, and a variety of other methods. The prospect of direct governmental provisioning and allocation of nature-based activities on the Northern Great Plains is somewhat small because less than $25 \%$ of this region is publicly owned. Moreover, less than $2 \%$ of the land area is both publicly owned and managed for biodiversity conservation. Indeed, most governmental approaches in this region consist of costly land purchases, placing politically unpalatable (if not constitutionally suspect) regulatory burdens for wildlife provisioning on landowners, and more successful efforts at incentive programs [40].

In between these two approaches is the prospect of formal collaboration among landowners. Four different legal tools are available. The first is contract law. Unlike purely informal arrangements, contracts are legally enforceable between the contracting parties. In the event of one party's breach, the payment of monetary damages is the preferred remedy [41] (p. 769). Contractual obligations do not 
ordinary extend to succeeding landowners; thus, the sale of a cooperating ranch will end part of the cooperative effort.

The second tool is property law. The property-law approach is similar in one key way to contract law and different in two important respects. At their core, property-law approaches to organizing collective action are contractarian in nature. The parties creating a property-based regime for resource allocation or provisioning may create an agreement that meets their needs and observes Ostrom's principles. The key differences between property law and contracts are the abilities to (1) vest the rights and duties of agreeing landowners in the title to the real estate (not simply among themselves) [42] (p. 470) and (2) enforce performance of the obligations in the event of breach, rather than limiting the parties' recovery to monetary damages [42] (pp. 490-491). As a result, these rights and duties can be enforced by and against subsequent owners of the affected real estate. For this reason, property law may be a superior choice when it comes to creating long-term tenure rights in the resource system that the parties create. As Ostrom has noted in her seventh principle, this is an important trait among long-enduring institutions.

The third tool is business-association law. Landowners could, for example, form a legal entity to which they would transfer title to their real estate in return for ownership interests in the entity. Once created, individual landowners would no longer own the real estate, but they would own shares of the entity owning and managing the real estate. Provisioning and allocation decisions could be made at the entity level. Of course, using a firm model in which multiple landowners are transformed into one institutional owner eliminates the need for cross-border collaboration. But it does not eliminate the problems associated with collective action. Thus, the institution created (the firm), should observe Ostrom's design principles in its internal governance, and the parties will have the ability to do so because business associations are largely contractarian.

The final tool is legislation enabling landowners to form a governmental entity - a special district - that is empowered to raise revenue and govern landowner activities to deal with provisioning and allocation problems $[34,35,43,44]$. Special districts are quasi-governmental, but they have aspects of a business association undergirding them because they are typically created to perform a narrow function and act in a proprietary capacity. Unlike purely private law approaches, this approach needs specific enabling legislation which, hopefully, would observe Ostrom's principles. This approach is also unique in its ability to overcome the holdout problem identified above in a way that none of the other mechanisms can [35]. Specifically, the formation of these districts can be statutorily designed to allow a quantum of willing landowners within a proposed geographic area to form the entity and include unwilling participants within its boundaries.

These four basic tools are not mutually exclusive. For instance, informal arrangements may be sufficient to provide the resources that a given operation needs, but perhaps a contract is necessary to govern allocation and access. Similarly, a property-based regime may work well for a group of landowners in need of heightened provisioning, but entity or governmental involvement might be better for allocation purposes. Thus, no single approach mentioned above should be taken as complete or isolated.

There are also many different legal arrangements that lawyers can create using these four tools, each with different parameters. For instance, the choice of a particular business association (e.g., a corporation, a limited liability company, a trust, etc.) may be influenced by tax policy and the 
particular state's law governing such entities' operations and authorized activities [45]. Within the property law setting, there are a number of ways to vary what we loosely refer to as property rights, including, for example, conservation easements and leases [42]. And special districts are as varied as they are common [46] (pp. 31-34).

Regardless of the approach selected, multiple choices will need to be made about what rights and duties should be created and how Ostrom's principles can be integrated into the structure. Thus, the capacity of the tool to accommodate the parties' needs emerges as a key consideration. In terms of the parties' autonomy to choose the terms of their arrangement, contract and property regimes are the most accommodating. Business associations follow closely behind. Special districts' ability to accommodate the parties' needs depends on the parameters of the legislation creating them. Because they are created by legislation, the scope of their authority is determined through political processes involving people other than cooperating landowners.

\subsection{The Common-Interest Community}

Common-interest communities are one example of formally ordering collective action that uses property law to deal with provisioning and allocation problems. I do not claim that a common-interest community is superior to other choices. Rather my point is to consider the capacity of a common-interest community to meet landowner needs in this setting in a way that ensures success under Ostrom's principles for institutional design. This focus is therefore somewhat narrow, but it can help landowners think about the issues that they will face. We also have experience creating and operating these institutions in other contexts, specifically in conjunction with residential developments. But, most importantly, this approach may help individuals in the private sector generate and capitalize upon nature-based activities that have historically been thought of as within the ambit of government. With the appropriate mechanisms in place, private law and the market can generate some of the environmental benefits that public-law approaches seek to generate. Realizing this potential is a strong argument for the institution of private property. Operating from a baseline of private ownership need not stifle conservation efforts. Rather, the legal tools available to landowners to vary their ownership rights allows for innovation that can achieve good wildlife outcomes, enhance ranch profitability, and foster the development of rural communities.

This section first describes a common-interest community in conceptual terms (3.2.1). It then discusses how the servitudes underlying a common-interest community could be used to deal with the provisioning and allocation problems a group of landowners may confront (3.2.2). However, the shortfalls inherent in a common-interest community built solely on servitudes counsel in favor of creating an institutional arrangement for solving provisioning and allocation problems. So I discuss how a common-interest community's association can be used to overcome those shortfalls and observe Ostrom's principles (3.2.3). The discussion of a viable common-interest association that observes Ostrom's principles continues with coverage of institutional control (3.2.4), revenue powers (3.2.5), and enforcement issues (3.2.6). 


\subsubsection{The Common-Interest Community Concept}

The common-interest community is a generic term for what most laypeople understand as the homeowners association used in residential development. In essence, these communities are founded upon rights and duties that inhere in the title to real estate and affect the property owners individually and collectively [47,48] (Chapter 54 \& 54A).

Individual ownership of a parcel of land within a common-interest community obligates the owner to engage in and refrain from certain land uses. For instance, in the urban setting, the construction and maintenance of the dwelling is often regulated, with an eye toward the aesthetic impact of the structures built on the property. Ownership of a parcel within the community also entitles the owner to membership in a community association. That association, in turn, may hold common property and maintain it for the benefit of the association members or perform certain functions for each owner. Bike trails, parks, and exercise facilities are typical examples of association property held for the benefit of the owners in common. Trash collection, snow removal, and lawn care are examples of services performed by an association for its members.

The association also performs administrative functions. It is primarily charged with the enforcement and administration of the restraints or obligations placed on individual owners. For instance, a landowner within a community that contains a restriction obligating each owner to seek pre-construction approval of a structure's design will seek such approval from the association-the entity representing the communal interest in each individual parcel. A landowner whose lawn or fence fails to comply with the covenants governing such matters would be detected and punished by the association.

These associations typically fund their activities with payments that landowners are obligated to make to the association as an incident of their ownership of an individual parcel. This revenue stream is then spent according to the direction given by the documents creating the association or the decisions made by the association acting under those founding documents. Increasingly, many associations are using the revenue they receive to provide services to the individual owners that were historically provided by government.

The specific parameters of a common-interest community are driven by the needs of the parties creating it, and the law governing these associations is flexible. Thus, Hyatt describes practice in this area as "box building." Clients have particular goals, values, experiences, and tolerance levels that impact how their effort should be structured. The lawyer's job, as Hyatt puts it, is to build a box that suits their needs and helps them achieve their goals. It needs to have the features they need and want, but without accessories that are useless or, worse, problematic [49].

Given the many variations that will emerge in the grasslands setting, it is difficult to posit how a particular common-interest community should look. However, there are some general aspects that bear discussion as a means of thinking about such a group's needs. What follows is a discussion of those aspects of common-interest communities, using the Restatement (Third) of Property for its legal foundation [50]. The Restatement, of course, is not law, but it is a helpful source of general principles and, importantly, vocabulary. Practitioners obviously know that the legal rules in their states may differ in certain respects from those restated in the Restatement. 
The first attribute of a common-interest community is its foundation - the servitude. The thing we call property is essentially a bundle of rights that individuals hold as an incident of land ownership. The term "servitude" under the Restatement (volume 1, p. 9), is a "generic term that describes legal devices private parties can use to create rights and obligations that run with the land." In essence, servitudes are a way of moving some rights from one owner's bundle and transferring them to someone else-here, other landowners seeking to collaborate. The property right implicated by the need for wildlife provisioning, for example, is the ability to use one's land as he chooses. When a servitude places an obligation on an owner to manage his land in a particular way for the benefit of his neighbors, it has transferred one of the rights in his bundle and placed it in his neighbors' hands. The same obligation placed on all lands in the group, with benefits that run to each of the other landowners, is a reconfiguration of the rights in the various bundles of each owner's property. Servitudes allow this sort of reconfiguration, allowing conceptual slices of property to move among the parties to the agreement [51] (pp. 842-846).

But moving slices of property in this way does more than reconfigure rights and obligations among the parties to the agreement. The slices become part of the property each landowner owns; they are a reconfiguration of the rights and obligations attending property ownership, regardless of who owns the property. One of the most important aspects of the rights and duties created with servitudes is their ability to run with the land. As the Restatement puts it (volume 1, p. 9) "Rights and obligations that run with land are useful because they create land-use arrangements that remain intact despite changes in ownership of the land." [50]. That is, a properly created servitude binds the land and, thus, the owner of that land, including subsequent owners who did nothing more than purchase the property. Because these rights and obligations run with the land, duration emerges as an important consideration. There are good reasons for establishing a termination date or a time for renewal, but the security that servitudes can provide to the enterprise is helpful. That security can, in turn, help attract funding for conservation efforts, spur individual investment, and, obviously, keep landowners from defecting to seek short-term gain without the assent of the group.

\subsubsection{Provisioning and Allocation through Servitudes}

Ostrom's first principle states that it is important to clearly define boundaries of the resource system and the individual rights to the resources created within that system. Thus, any effort at provisioning and allocation must take care to identify what precisely the parties seek to collectively provision and the individuals' allocation rights.

With regard to provisioning problems, servitudes can be placed on all landowners within the group establishing the rights and obligations the parties conclude are necessary to the provisioning activities they choose to undertake. With regard to wildlife, for instance, each owner should agree to manage his or her land in a way that enhances and supports the wildlife population for the benefit of other owners within the group. The servitudes can also grant each landowner access to each other's properties to conduct use activities like hunting and wildlife viewing. With regard to trails and campgrounds, the parties can configure the obligations associated with construction and maintenance.

Allocation problems can also be addressed through servitudes. Thus, the servitudes may place limitations on the number of visitors, the amount of game that can be harvested, the timing and 
intensity of use activities like hiking, horseback riding, and camping, as well as other matters falling within the realm of allocation problems.

The need for clarity and the number of provisioning and allocation issues that parties may confront complicate matters for landowner groups in the grasslands context. In other settings, deciding on the rights and obligations necessary to make the project work is not all that difficult. It is not particularly difficult, for instance, to come up with a set of restrictions that limit the types of grass to be planted in lawns or that limit the height of, or the materials to be used in, fences. Both correspond to the idea of beauty (or the potential for profit) employed by those drafting the servitude. Matters are not that simple with managing grasslands for the purpose of enhancing the presence of wildlife and using those lands for ranching and nature-based activities. The science of grasslands management will be of keen importance, but there is a great deal of uncertainty concerning what land uses will and will not be beneficial to the overall effort. Intensive grazing, controlled burns, introduction of species, stocking ratios, fencing and fence removal, and a variety of other aspects of land management will be important. And operating at a large scale may mean that some lands will need to be treated differently than others because of their physical location or ecological significance. Inventorying species will be an important step in making management choices and, depending on the data, provisioning obligations and allocation rights may need to change over time. Further difficulties are likely to ensue from the uncertain nature of the returns certain activities may yield, as well as uncertainty concerning the level of use that pooled resources can sustain. Indeed, experimentation and adaptive management may be the only truly workable approaches to effective provisioning and allocation in this context. [31,32] Unlike the residential property setting, where manicured lawns and no-wood fences for every parcel in the development correspond to a collective view of beauty or have been proven in the marketplace to enhance value, the outcomes here are more uncertain and the choices associated with generating those outcomes can be complex.

Dealing with this complexity can be accomplished by engaging experts and fashioning the servitudes at a highly detailed level, requiring landowners to perform certain practices and allow certain levels of use. This has the upside of some level of certainty, but the prospect of change or failure must be adequately taken into account. To do so, at the least, an amendment mechanism should be employed [47] (pp. 455-457). Thus, the landowners would be given the power to amend the servitudes under a set of procedures spelled out in the servitude. The requisite quantum of owners involved in the amendment process could vary from majority rule (by participant or by acreage or whatever) to unanimity. Again, the choice would be one for the group. Detailed servitudes would be consistent with Ostrom's first principle of clear boundaries, and an amendment mechanism could be drafted in a way that observes her third principle of collective choice.

A further level of complexity emerges, however. Allocation decisions are often influenced by the contributions that each member makes to provisioning the common resource. Ostrom makes this relationship explicit in her second principle: an effective collective action institution maintains proportionality between the benefits and costs experienced by individuals within the group. Thus, the provisioning obligations and allocation rights contained in a set of servitudes should be crafted in a way that ensures proportionality between costs and benefits. Achieving this congruence between relatively complex provisioning and allocation choices brings a further level of difficulty to the parties. For instance, valuing a provisioning contribution could quickly raise questions of the metric by which 
it should be judged (e.g., by the environmental benefits flowing from the improvement, the costs associated with it, or both). Determining the value of allocations could involve similarly difficult questions. And those two difficulties are both present when one seeks to maintain proportionality between provisioning costs and allocation benefits. Again, an amendment mechanism would be an important means of maintaining proportionality between costs and benefits going forward.

However, given the potential complexity of the rights and duties at issue and the need to maintain proportionality, it may not be feasible to state the provisioning obligations and allocation rights at a high level of detail. There will likely be a need to continually adapt provisioning measures and adjust allocations. Indeed, it may be that the enunciation of standards or goals (as opposed to rules and concrete obligations) is nearly all that can be set forth with any certainty at the outset. Moreover, the creation of obligations and rights does little to ensure enforcement and does not give the parties any sort of a financing mechanism to help pay enforcement or management costs or hire assistance. However, a common-interest association can solve many of these problems or at least give the parties a means of dealing with them.

\subsubsection{Common-Interest Associations}

Servitudes for common-interests communities often create a common-interest association with governance and revenue-raising authority [52]. The association can be formalized as a separate legal entity (for example, as a limited liability company, corporation, or trust) or it can exist as an unincorporated association [48] (p. 54A-18). In any event, the servitudes will vest each member of the group with membership in the association as an incident of their property ownership. The association is then vested with the authority to administer the servitudes.

The common-interest association is a good option for dealing with the complexity of the obligations involved in this context. An association can be empowered and limited in whatever way the parties deem appropriate. For instance, the association could be vested with the power to contract with experts in habitat and wildlife to seek input on what measures are likely to yield the greatest return, thus helping the parties deal with the operational challenges mentioned above. More importantly, using an association can allow the parties to frame obligations at a fairly broad level. That is, the servitudes can provide the association with discretion to determine what landowners must do in order to attain their collective goals, leaving sufficient leeway to engage in an adaptive effort. By vesting individual landowners with membership in an association that will, in turn, administer servitude obligations within the group, the landowners can free themselves from the need to enunciate fine-grained servitudes spelling out each participant's rights and obligations. Rather, the association's power to create rules concerning provisioning and allocation can be set forth in the servitudes along with an obligation for each landowner to abide by those rules. In essence, then, the landowners will create an entity through which they may govern themselves, creating and adjusting the rights and duties necessary to adequately provision and allocate the resources at issue and maintain proportionality between costs and benefits for individual participants.

An analogy can be drawn here to the issue of design standards for houses built within residential common-interest communities [47] (pp. 345-347). In some instances, the servitudes impose specific requirements on landowners within the development to use certain materials or build to a minimum 
size. However, beyond those parameters, care must be taken to ensure that homes being built do not diminish the value of surrounding properties. In this regard, many servitudes that govern residential common-interest communities empower the association to review plans for proposed structures and require landowners to get that approval before they start building. Standards are often set forth at whatever level of specificity the developer chooses, and it is good practice to define the standards in terms that are as concrete as possible. But to a greater or lesser extent the association (the members acting collectively) are given the discretion to approve or deny proposals based upon those standards. The same principles can be employed in the grasslands setting.

\subsubsection{Voting, the Right Level of Association Discretion, and Collective-Choice Problems}

The use of an association does not, however, relieve the parties of the need to develop clear rights and obligations for the participants, as Ostrom has observed as her first principle of successful institutions. Rather, it simply provides a vehicle through which specificity can be developed and adapted to the needs of the parties and the success of the effort. In broader terms, of course, the lessons of public governance are applicable to private-governance design. Procedure, minority rights, decisionmaking standards, and the like are all elements of good government. They are elements of good governance as well. In creating these regimes, the practitioner and participant should be careful to avoid what they deem the pitfalls of government and strive to incorporate its most laudable aspects. This effort at private governance is, after all, limited largely by what level of collective control the participants will tolerate within these communities.

The question of how much discretion to give an association-how broadly or narrowly to frame the servitudes that the association will administer-depends in large part on the level of control each individual member will have in the association. Control will be determined though (1) the voting rights that each member has and (2) the quantum of votes necessary to take a particular action. The servitudes will make each landowner a member of the association and give him or her control in the form of voting rights. The allocation of voting rights need not, however, be "one person, one vote." Perhaps each member should have equal say. But a group could easily conclude that each member's share of control should be determined according to the acreage he or she holds. Or perhaps each member's share of control should depend upon an environmental benefits index that would, in turn, provide a further incentive for the creation of such benefits on the lands involved. Additionally, the quantum of voting interests necessary to take a particular action could vary from a bare majority to unanimity and could vary according to the type of decision at issue.

The possibilities are numerous, but the general idea is one of a governance structure that administers the obligations and entitlements created through the servitudes. In the grasslands context, the benefits of democratic private governance are similar to those in other contexts. It is a means for collective choice with a particular set of goals in mind. It provides, in essence, a mechanism for community-level control of land uses impacting others within the community. To the extent a landowner is satisfied with the process (if not the result) and is assured of a continuing voice in the association's operation, he or she is more likely to join the collective effort, remain engaged, and resist the temptation to defect. 
This sort of a governance regime has the sort of stakeholder participation that Ostrom has observed in her third principle: participants affected by allocation and provisioning rules are included in the group who can modify these rules. All landowners are affected by the rules they create through the association and they have the power to change those rules when they see a need for it.

Although the subject is too broad to engage meaningfully in this article, significant difficulties can arise when one considers association control in light of the need to maintain proportionality between benefits and costs. An economic incentive exists for those in control to take more than their fair share from the enterprise. Thus, the challenge facing the parties is to create a structure in which controlling participants are less likely to expropriate benefits from minority interests.

There are at least six potential checks on this sort of opportunism. The first is the choice to exit the arrangement. For example, termination provisions could be used to protect minority rights. But if minority interests are given a tool by which they can keep controlling interests in check, then the potential arises for those minority interests to use their authority and expropriate undue benefits from the majority. Another form of exit is each individual's ability to sell the land to a new owner. But exit through sale may do little more than give the seller the ability to find a willing buyer who will discount their purchase price in light of the problems the new buyer will be likely to encounter. So selling the property does little to protect the seller from majoritarian overreaching. The second check has to do with the level of discretion afforded the association. Perhaps the parties will choose to limit the governance authority of the association in relation to provisioning and allocation questions. But spelling out such matters in detail within servitudes poses the problems I've discussed above. The third has to do with the quantum of votes necessary to take action on provisioning and allocation questions. Unanimity would, of course, avoid majoritarian overreaching. But deadlock could ensue. The fourth has to do with the allocation of voting power. Perhaps a creative lawyer can fashion a mechanism vesting control among members based on their relative contributions to the enterprise. But there are significant metric problems that could arise. The fifth has to do with the longevity of the enterprise. Perhaps over the long term, power shifts, contributions, and benefits will balance despite a disconnect between costs and control. But the parties have no assurance that will happen, nor do we know the time frame in which it might happen.

The sixth, and perhaps the most likely, check is the social settings in which these enterprises are likely to emerge. Perhaps landowners will be as concerned about what their neighbor gets as they are about what they get. Such a phenomenon is not unheard of within close communities or small enterprises. On the other hand, social ties often cut both ways. Neighbors fall out of favor with one another and seemingly unrelated conflicts can trickle into association governance and decisionmaking. In the end, there may be no good way to deal with this problem. However, participants should discuss the issue and think about how they want to deal with it in designing their institution.

\subsubsection{Revenue Powers}

Very often, servitudes in a common-interest community involve an obligation to pay money to an association to fund association activities. The servitude may spell out (or the association may be given the authority to determine) the amount of the fee, the metric for its calculation, and the purposes for which the revenue may be spent. This can give the group a means of financing its activities, sharing 
costs at a communal level. Obviously, it will take money for the association to undertake certain improvements. For instance, the removal of invasive species could be financed through the association. Each owner's stake in the operation could also be solidified by his or her payment to the association and the expectation that the funds will be spent on improvements or maintenance that inure to the landowners collectively.

The need to keep costs and benefits proportional for individual participants can be enhanced with a revenue mechanism, thus providing an additional means of observing Ostrom's second principle concerning the link between provisioning costs and allocating benefits. Compensation from association revenue for disproportionate landowner provisioning (which benefits the association as a whole) can be used to keep provisioning and allocation congruent. For instance, suppose one area of land within an association needs to undergo a controlled burn, but the loss of acreage for the time period associated with the practice will be particularly detrimental to one or more ranchers. The funds generated for the association through the payment of dues could be spent to help compensate the individual rancher for his or her lost income without having to reallocate the resource entitlements to maintain proportionality. In short, compensation allows for congruity without continually altering allocations.

Lost income, of course, is just one metric by which disproportionate costs can be detected. Others would include comparing the value of a member's provisioning activities to the value of a member's allocation. As mentioned above, determining those values can become a complex task, but an association can be given the discretion to experiment as it determines when and how its revenue should be distributed.

Alternatively or additionally, revenue obligations to the association could be calculated based on resource-based income and used to compensate members for their provisioning activities, perhaps in lieu of altering access rights among individual properties. This sort of a fee structure would redistribute some members' income to those members who contributed to provisioning the resources but were unable to realize the benefits, perhaps due to a lack of access to those resources. This would also help keep benefits and costs proportional among the members and could be used in instances where landowners are unwilling to give their neighbors access to their properties. Identifying how compensation should be distributed would also involve the selection of a metric for valuing provisioning contributions.

\subsubsection{Enforcement Principles}

Participants should also consider enforcement provisions in designing a common-interest association. Three objectives are particularly important: (1) providing a quick and low-cost means of conflict resolution, (2) having accountable monitors, and (3) punishing violations with proportionate sanctions. All of these relate to the idea of enforcement.

Ostrom has observed in her sixth principle that many successful collective action institutions involve " $[\mathrm{u}]$ sers and their officials [who] have rapid access to low-cost, local arenas to resolve conflict among users or between users and officials." [37] (p. 259). Judicial enforcement of the obligations and rights created in a private law setting is the default means of resolving conflicts in the United States. Such a forum can be time consuming and often costly, but it is often local given the way state 
courts are organized. Alternative dispute resolution techniques, like arbitration, are an alternative. Additionally, the servitudes could set up a dispute resolution process within the association. That, in turn, could be designed with low-cost and rapid-response considerations in mind. Dispute resolution could also occur informally, which may be likely in this setting.

Ostrom has also observed in her fourth principle that successful institutions often have "monitors, who actively audit biophysical conditions and user behavior, are at least partially accountable to the users and/or are the users themselves." [37] (p. 259). Such institutions, under her fifth principle, punish violations of allocation and provisioning rules with graduated sanctions that depend on the seriousness and context of the offense. An association monitoring the activities of its members would provide the sort of self-governance that Ostrom has found elsewhere. Graduated sanctions could be formalized in an association's founding documents or simply imposed by the association as it operates. The Restatement also explicitly recognizes in Section 6.8 the ability of common-interest associations to "adopt reasonable rules and procedures to encourage compliance and deter violations" [50]. In so doing the association should observe the principle of graduated sanctions.

\subsection{Possible Legal Reforms}

One key benefit of a common-interest community approach to solving allocation and provisioning problems is the ability to utilize existing legal tools. There is no need to wait for large-scale legislative reforms before embarking on a private sector effort. However, the role of the state is not altogether irrelevant to organizing collective action using existing private-law tools. As Ostrom has concluded in her seventh principle, the long-term success of collective-action institutions depends in part on the absence of external government resistance to the institution [37] (p. 259). Under this principle, users must also have the ability to create long-term tenure rights in conjunction with the resource [37] (p. 259). The ability to create such long-term tenure rights depends in part on governmental recognition and protection of those rights. Thus, one must examine the level of governmental support for these efforts even though government is not the primary actor. The line between public and private is, after all, somewhat fleeting.

There are two primary concerns that arise here. The first is with the history of regulation concerning wildlife in the United States. The second is with the law of servitudes. I address these concerns and possible legal reforms for each below. Overall, however, the need for legal reform is far from clear. The United States has a long history of individual land ownership that sanctifies individual choice with regard to excluding others from within one's geographic property boundaries and gives landowners a great deal of freedom to determine how their lands are used. Thus, to the extent we are simply talking about ordering land uses in the private sector, government may not challenge that authority and the ability of ranchers to create long-term entitlements. But given the confluence of land use, wildlife, and servitude law, concerns exist.

The history of governmental control over wildlife resources raises the prospect of challenge by external governmental authority. Many states currently allocate access to wildlife resources through permit mechanisms or other sorts of hunting regulations. In Nebraska, for example, allocation of large game species like deer is made through a permitting system in which non-transferrable permits are sold to hunters or distributed to landowners. Geographic limits on permits enabling a permitee to take 
a particular species within a given geographic area are also a common feature of regulated hunting. For other types of game, like upland birds, hunting is restricted to a particular number of days and a limit is placed on the number and sex of the species that each individual hunter can take. Regardless of the particular approach, game utilization is highly regulated, with an underlying ethic that game is public property to which individuals are given access on the government's terms [53] (pp. 160-161). Title 163, Chapter 4, of the Nebraska Administrative Code-the Nebraska Game and Parks Commission's regulations pertaining to wildlife - is a good example of allocation regulations [54]. Given this state of affairs, government may resist the sort of effort posited here.

However, in some states landowners are becoming more involved in game management. For instance, in Colorado, landowners do receive transferrable hunting permits that they can sell [55]. Thus, the private sector may be emerging as an important part of wildlife management. Further support for this claim can be found in the recently enacted Voluntary Public Access and Habitat Incentive Program, administered by the Farm Service Agency within the United States Department of Agriculture. A product of the 2008 Farm Bill, this program provides grant funding to state governments "to encourage owners and operators of privately-held farm, ranch, and forest land to voluntarily make that land available for access by the public for wildlife-dependent recreation, including hunting, fishing, and other compatible recreation and to improve fish and wildlife habitat on their land, under programs administered by State or tribal governments." [56] (p. 39135). That grant money is, in turn, used to compensate landowners for granting access to the public for nature-based recreation.

Given the need for making progress on privately owned lands, the system could be changed to further decrease the prospect of challenge by external governmental authorities. A strong argument can be made that no permitting system should be necessary for game hunting within a common-interest community like that mentioned above. All landowners within it have an incentive to manage game populations for their own benefit and will make the allocation decisions necessary to sustain their effort. Indeed, we do not require a permit to slaughter a certain number of cattle. Much the same could be said for game within associations where the game benefits landowners.

However, scrapping permit systems for game hunting would be a somewhat dramatic change in American wildlife law. American law is replete with laws regulating hunting, including hunting on private property. Depending on the species, game management can take a variety of different forms, but it is seldom the case that landowners are left with absolute discretion to hunt or allow others to hunt a particular species. Perhaps the only examples of such an unregulated approach are those species that are regarded as pests or those that a landowner concludes are damaging his or her property [57].

Indeed, it may not be good policy to eliminate the state's wildlife management role. State-level data collection and management can be used to control external impacts, for instance with regard to game that travel beyond the common-interest community's boundary. And, as in the cattle industry, there may be public health issues associated with wildlife management that necessitate state involvement. In this context, the additional prospect of landowners focusing on certain species and species' traits provides a further level of concern if biodiversity conservation is a policy goal. Many states have also developed the knowledge and facilities necessary to make management decisions. Thus, it may be more efficient to preserve the state's wildlife management role, perhaps in the form of requiring common-interest communities to submit wildlife management plans to a state agency for its approval. 
Moreover, the political support of public wildlife managers has been an important ingredient in the emergence of these institutions in countries like Namibia [24] (pp. 31-32). Thus, providing a role for public wildlife agencies in the development of these institutions may benefit landowners, as well as the public.

Another option for state involvement is to have it calculate game allocations. Thus, it could determine the overall numbers of species that can be harvested within the common-interest community's boundaries. Further allocations could then be made by the association among the various landowner members. In conjunction with such a unitized allocation, a number of transferrable permits could be issued to the association or to the landowners within the association. To the extent a permitting regime remains, the transferrable permit could be sold in conjunction with the association or landowner's operation. In any event, state allocations to associations, perhaps in conjunction with a set of standards the association would need to meet to qualify for the issuance, would provide a strong incentive to form these groups. It would also acknowledge governmental support and allay participant concerns about governmental challenges. A governmental commitment in the form of legislation would also stabilize the association's long-term tenure rights in the resources and lessen the threat of governmental interference with their operations.

The law of servitudes may also need some change in order to solidify landowners' ability to create long-term tenure rights. Here, the law is somewhat murky. The law of servitudes is a complex doctrinal area that I have generalized and simplified for purposes of this article. In reality, there are various conveyances involved in the present context. To the extent we are talking about giving others the right to enter another person's land for a particular purpose (hunting, camping, or whatever) or take game from the property, the law of servitudes is relatively clear in allowing landowners to create such rights and duties, and it enforces those rights and duties among subsequent owners of the real estate. However, one aspect of servitude law raises concern. Concern arises when a landowner attempts to obligate himself and successive owners to pay funds to a common-interest association, maintain the property for wildlife habitat, or provide suitable habitat. Historically, courts have refused to enforce some use restrictions and affirmative obligations on subsequent owners of real estate [58]. The doctrinal grounds and their policy rationales vary, but many courts have been concerned about the threat such obligations pose to the value and alienability of land as well as to the free use of land by subsequent owners. Modern courts have eroded these doctrines because of the importance of servitudes to land development and the benefits they can be used to create, but judicial reluctance to enforce these sorts of obligations still exists in some states [52]. In those states where this remains an issue, legislation could override the judicial rules. Alternative approaches, like special districts or entity ownership arrangements, should also be considered in such states.

\subsection{Doing More with Common-Interest Communities}

Thus far, this article has focused on the common-interest community and its attendant association as a collective governance mechanism. Through such an arrangement, multiple landowners can come together to provide for common resources and decide upon the allocation of those resources in a way that transcends the geographic property lines between their properties. I have assumed that each landowner would utilize the allocated resources to provide income to their own operations. However, 
there are a number of permutations that can arise once the landowners start collaborating across their property boundaries.

For instance the discussion above assumes that the servitudes will benefit and burden each landowner reciprocally and that the association would decide on the finer points of provisioning and allocation. However, another option would be to make the association the beneficiary of all the obligations placed on the properties. Thus, the association would have access to the properties for hunting, hiking, wildlife viewing, camping, or whatever other uses there are of the provisioned resources. Under this sort of an arrangement, the association could operate more as a business venture and determine how to distribute the revenue to the association's members. In other words, the allocation function of the association would turn from ordering the allocation rights of individuals in a resource to distributing earnings to the individuals. This approach would be very close to a business-association approach described briefly above, even though each landowner would continue to own his or her ranch.

One could also envision a scenario under which the association contracts with a third-party outfitter to use the resources that have been effectively pooled at the associational level. The payment such an outfitter would make to the association in return for this utilization would then be distributed to the association's owners.

Common-interest associations also often hold common property-land or structures owned collectively by the group through the association. Such an arrangement may be helpful in this setting if the landowners would like to collectively acquire more land or jointly build facilities to assist them in their efforts.

The association can also act as a focal point for dealing with other entities. For instance, the association could compete for grant money that is to be spent on wildlife habitat. A group of landowners operating through an association that has some level of control of a vast acreage may compete very effectively for such funding.

An interesting example of this structure is the NamibRand Nature Reserve in southwestern Namibia [24]. Although it operates on a not-for-profit basis, its organizational structure entails an arrangement whereby individual landowners retain the fee title to the real estate. The owners, however, have joined the reserve (a sort of association that the landowners govern) and have given it the authority to utilize and manage the property for biodiversity conservation. In addition, the reserve grants concessions to third parties that conduct low-impact ecotourism activities on the property in exchange for a fee. That fee is used by the reserve to cover its operating costs and any surplus is retained for further conservation efforts. In a for-profit enterprise, of course, that surplus would be distributed to the members.

\subsection{Distinguishing Conservation Easements and the Land Trust Model}

The common-interest community approach is somewhat similar to the conservation easement and land trust model that is common in the United States. Airey provides an excellent legal overview of this model [58]. Basically, a conservation easement is one type of servitude and a land trust is typically the beneficiary of such easements. A land trust holds the development rights on property that the owners have agreed not to develop. The landowner still retains possessory rights and the underlying 
fee to the realty, along with the ability to use the land for agricultural or other permissible uses. The land trust is typically a non-profit organization that holds and enforces the easement.

As mentioned above, there is some uncertainty about the long term enforceability of these servitudes in the grasslands context. The same was true of conservation easements. Thus, conservation easements are a common subject of specific legislation enabling their use. Under the enabling legislation, conservation easements can only be held by specific entities, typically governmental entities and charitable organizations. The adoption of that legislation is also complemented (and perhaps driven) by federal tax provisions that allow for an income tax deduction for the value of a conservation easement donated to a qualifying charitable organization. A condition commonly allowed in the enabling legislation (and required by federal tax law) is that the easement be perpetual.

There is, of course, much more to the land trust model than what I have set forth here, not the least of which is federal income tax treatment [59,60]. But two primary distinctions between the common-interest community approach and the land trust model are worth mentioning. First, it may not be possible to create the sorts of servitudes that ranch owners will need for this effort while satisfying the requirements of state conservation easement legislation. However, most states allow a great deal of leeway in how the parties frame the obligations and rights under a conservation easement, so that distinction may not be as significant as the second.

Second, the governing entity is different. The common-interest community approach would involve the formation of a common-interest association among existing landowners. The land trust model, by contrast, would likely involve a land trust or charitable corporation that is controlled by third parties. Thus, the land trust may fall outside the community of landowners and be controlled by people who do not share the same interests or values as the landowners. Interjecting a value set that is different from those who are subject to the servitude may complicate matters.

Landowners could solve this second complication by forming their own qualifying entity and conveying conservation easements to it. To do so, however, the parties must be able to function as a charitable entity. In Nebraska, for example, qualified non-governmental holders of conservation easements must be charitable corporations or trusts [61]. In the grasslands context, one driving force behind the effort is to increase the profitability of the landowners within the enterprise. And, in some instances, the association may carry on the profitmaking venture. In the latter arrangement, charitable status is non-existent. In the former, it is still questionable.

\subsection{The Relative Benefits of Formalized Private-Law Arrangements}

The private-law collective-action approach described here stands in contrast to the regulatory approach of controlling land uses for the benefit of species and habitat. The goal of environmentally sound and biologically diverse landscapes can be achieved through governmental regulation of resource use. However, even though the goals of such an effort may be laudable, it often encounters landowner resistance. Such resistance can take the form of claims for compensation for the "taking" of one's property or simple political resistance to the notion of governmental interference. One upside of the approach presented here is its grassroots effort at achieving good environmental outcomes in an economic system that allows producers to profit from the spending public's demand for these important places. In that sense, government does not dictate the result; the market produces it. This 
does not mean, however, that the governmental role is absent or insignificant. The legal regime within which an association operates is, after all, backed by the state.

It is more difficult to determine whether or not a formalized private-law approach is better than an informal arrangement among landowners. One could argue that these regimes are only likely to exist (let alone thrive) in communities where a high level of informal control already exists. Even then, however, the effort at formalization has utility. First, formalization carries with it enforcement mechanisms that may be superior to those that exist with informal efforts. Second, formalization requires the parties to think rigorously about the issues facing the group. The effort at formalizing the group's effort is thus formative and, hopefully, produces a workable framework within which the community can better achieve its goals. Finally, a formalized legal arrangement is more likely to garner governmental recognition and cooperation. That, in turn, may open up opportunities for better environmental outcomes than are achievable through informal arrangements or purely regulatory approaches.

The newly created Cooperative Conservation Partnerships Initiative, administered by the Natural Resources Conservation Service (NRCS) within the United States Department of Agriculture, is an example of federal funding that may work well in this area [62]. The program, created by the 2008 Farm Bill, allows for the NRCS to partner with producer associations and other entities to deliver program funds to individual producers for conservation practices and improvements [63]. A common-interest community like that described here may qualify as a producer association and may be eligible to partner with the NRCS to support federal funding for producer's efforts.

Another possibility is the newly created Voluntary Public Access and Habitat Incentive Program mentioned above. A group of cooperating landowners may compete well for such funding, depending upon how the state grantees structure their efforts at promoting wildlife and wildlife habitat within their private lands programs.

\section{Conclusions}

The common-interest community may be a viable means of facilitating collective nature-based entrepreneurial efforts on ranchlands. It can provide the participants with the benefits of geographically larger operations without purchasing additional land, a governance mechanism for making provisioning and allocation decisions in an adaptive context, a revenue device for spreading the costs of management practices or improvements among the participants, and the opportunity to generate income from utilizing the resources they have created. Participants will need to think about whether the profit-making enterprise is to be conducted at the association level, and there are numerous other factors that must be considered in setting the parameters of the servitudes and the structure of the association. In the end, however, none of these challenges is particularly insurmountable. A group of motivated ranchers who see value in providing nature-based opportunities can overcome them. If successful, their ranches may become more multi-functional and more profitable.

Ranchers on the Northern Great Plains are, of course, not alone in this effort. As I mentioned at the outset, there are a variety of examples across the globe. The literature cited in this article helps collect these valuable lessons, which will be helpful in making a sustained effort at private-lands conservation 
in the United States [21-26,28,64]. On the institutional design front, of course, we have many examples of working endeavors in other contexts in the United States. From grazing associations to cooperatives, and from inland fisheries to groundwater management districts and homeowners associations, the ability of people to do together what they cannot do alone and to avoid Hardin's tragedy pervades. This paper brings some of this together. But there is much more to be done.

More broadly, private-sector involvement in producing and offering opportunities to experience important and unique ecosystems is a subject that should not be ignored in the debates concerning the proper balance between private property and governmental control of natural resources. Creating broad rights of landownership and fragmenting a landscape with property boundaries, as we have done in the United States, does not necessarily lead to tragic results in the long term. Indeed, we may be at a place in our development of the Great Plains where consumer demand for natural places can operate to reconfigure the boundaries of property ownership to produce the ecosystem goods and services that consumers and the public value.

\section{Acknowledgements}

Financial support from the University of Nebraska College of Law and a McCollum Research Grant are gratefully acknowledged. Many thanks as well to the helpful comments of the anonymous peer reviewers, Steve Bradford, Steve Willborn, Richard Moberly, Tyler Sutton, Larkin Powell, Rick Edwards, Joel Mintz, and John Dernbach.

\section{References and Notes}

1. Cordell, H.K. The latest on trends in nature-based outdoor recreation. Forest History Today, Spring 2008, pp. 4-10

2. Edwards, R.; Thomspons, E. The role of conservation research and education centers in growing nature-based tourism. Gt. Plains Res. 2010, 20, 51-70.

3. Johnson, B.; Blumendahl, B.; Lukassen, R. Nebraska Farm Real Estate Developments; University of Nebraska: Lincoln, NE, USA, 2008.

4. Morrisette, P. Conservation easements and the public good: Preserving the environment on private lands. Natur. Resour. J. 2001, 41, 373-426.

5. Freese, C.; Montanye, D.; Forrest, S. Proposed standards and guidelines for private nature reserves in the northern great plains. Gt. Plains Res. 2010, 20, 71-84.

6. Ocean of Grass: A conservation Assessment for the Northern Great Plains; Northern Plains Conservation Network: Bozeman, MT, USA, 2004.

7. Edwards, R.; Reading, R.P. Saving the world's grasslands. Gt. Plains Res. 2010, 20, 5-7.

8. Davidson, J. North America's Great Carbon Ocean. Prairie Fire, June 2010.

9. Ruhl, J. Farms, their environmental harms, and environmental law: Taking the great leap from anti-law to positive law in farm policy. Ecol. Law Quart. 2000, 27, 263-349.

10. Ruhl, J. Three Questions for Agriculture about the Environment. J. Land Use Envtl. L. 2001, 17, 395-408.

11. Ruhl, J. Farmland stewardship: Can ecosystems stand any more of it. Wash. UJL Pol'y 2002, 9, 1-20. 
12. Secretary's Memorandum 1056-001: Establishment of the Office of Ecosystem Services and Markets; United States Department of Agriculture Office of the Secretary: Washington, DC, USA, 2008.

13. Ruhl, J.B.; Kraft, S.E.; Lant, C.L. The Law and Policy of Ecosystem Services; Island Press: Washington, DC, USA, 2007.

14. Ruhl, J.; Salzman, J. Law and policy beginnings of ecosystem services. J. Land Use Envtl. L. 2006, 22, 157-172.

15. Daily, G.C. Nature's Services: Societal Dependence On Natural Ecosystems; Island Press: Washington, DC, USA, 1997; p. xx.

16. National Agricultural Library, United States Department of Agriculture. Community Development Resources: Tourism; Available online: http://ric.nal.usda.gov/nal_display/index.php?info_ center=5\&tax_level=2\&tax_subject=211\&topic_id=1169\# (accessed on 17 March 2010).

17. Agricultural Marketing Resource Center. Agritourism; Available online: http://www.agmrc.org/ commodities_products/agritourism/ (accessed on 17 March 2010).

18. Freese, C.; Montanye, D.; Dabroska, K. New Directions for the Prairie Economy: Connecting Conservation and Rural Development in the Northern Great Plains; World Wildlife Fund: Washington, DC, USA, 2009.

19. Switzer Ranch Homepage. http://switzerranch.com/ (accessed on 17 March 2010).

20. Calamus Outfitters Homepage. http://www.calamusoutfitters.com/index.htm (accessed on 17 March 2010).

21. Hoogesteijn, A.; Hoogesteijn, R. Cattle ranching and biodiversity conservation as allies in South America's flooded savannas. Gt. Plains Res. 2010, 20, 37-50.

22. Langholz, J. Global trends in private protected areas and their implications for the northern Great Plains. Gt. Plains Res. 2010, 20, 9-16.

23. Maude, G.; Reading, R.P. The role of ecotourism in biodiversity and grassland conservation in Botswana. Gt. Plains Res. 2010, 20, 109-119.

24. Odendaal, N.; Shaw, D. Conservation and economic lessons learned from managing the Namibrand Nature Reserve. Gt. Plains Res. 2010, 20, 29-36.

25. Sundaresan, S.R.; Riginos, C. Lessons learned from biodiversity conservation in the private lands of Laikipia, Kenya. Gt. Plains Res. 2010, 20, 17-27.

26. Swift, B.; Arias, V.; Bass, S.; Chacon, C. Private lands conservation in Latin America: The need for enhanced legal tools and incentives. J. Envtl. L. Litig. 2004, 19, 85-139.

27. Langholz, J. Economics, objectives, and success of private nature reserves in Sub-Saharan Africa and Latin America. Conserv. Biol. 1996, 10, 271-280.

28. Hoogesteijn, R.; Chapman, C. Large ranches as conservation tools in the Venezuelan llanos. Oryx 2009, 31, 274-284.

29. Lobao, L.; Schulman, M.; Swanson, L. Still going: Recent debates on the goldschmidt hypothesis 1. Rural Sociol. 2010, 58, 277-288.

30. Greater Gracie Creek Landscape; Available online: http://www.nebraska.audubon.org/neIBAsp27.htm (accessed on 31 May 2010). 
31. Salafsky, N.; Margoluis, R.; Redford, K.; Robinson, J. Improving the practice of conservation: A conceptual framework and research agenda for conservation science. Conser. Biol. 2002, 16, 1469-1479.

32. Karkkainen, B. Collaborative ecosystem governance: Scale, complexity, and dynamism. Va. Envtl. LJ 2002, 21, 189-243.

33. Lincoln Institute of Land Policy. Regional Collaboration; Available online: http://www. lincolninst.edu/subcenters/regional-collaboration/ (accessed on 17 March 2010).

34. Ellickson, R. New institutions for old neighborhoods. Duke Law J. 1998, 48, 75-110.

35. Elmendorf, C. Securing ecological investments on other people's land: A transaction-costs perspective. Natur. Resour. J. 2004, 44, 529-562.

36. Ostrom, E. Governing the Commons: The Evolution of Institutions for Collective Action; Cambridge University Press: Cambridge, UK, 1990; p. xviii.

37. Ostrom, E. Understanding Institutional Diversity; Princeton University Press: Princeton, NJ, USA, 2005; p. xv.

38. Ellickson, R.C. Order without Law: How Neighbors Settle Disputes; Harvard University Press: Cambridge, MA, USA, 1991; p. ix.

39. Ellickson, R. Property in land. Yale L. J. 1992, 102, 1315-1400.

40. Stern, S. Encouraging conservation on private lands: A behavioral analysis of financial incentives. Ariz. L. Rev. 2006, 48, 541-584.

41. Farnsworth, E.A. Contracts, 3rd ed.; Aspen Law \& Business: New York, NY, USA, 1999; p. xxv.

42. Stoebuck, W.B.; Whitman, D.A.; Cunningham, R.A. The Law of Property, 3rd ed.; West Group: St. Paul, MN, USA, 2000; p. xxi.

43. Thompson, B., Jr. Conservation options: Toward a greater private role. Va. Envtl. LJ 2002, 21, 245-316.

44. Elmendorf, C. Ideas, incentives, gifts, and governance: Toward conservation stewardship of private land, in cultural and psychological perspective. U. Ill. L. Rev. 2003, 2, 423-505.

45. Goforth, C.R. An Overview of Organizational and Ownership Options Available to Agricultural Enterprises; University of Arkansas School of Law: Fayetteville, AR, USA, 2002.

46. Reynolds, O.M. Local Government Law, 3rd ed.; West Group: St. Paul, MN, USA, 2009; p. xvii.

47. Hyatt, W.S.; French, S.F. Community Association Law: Cases and Materials on Common Interest Communities, 2nd ed.; Carolina Academic Press: Durham, NC, USA, 2008; p. xxxi.

48. Powell on Real Property; LexisNexis Matthew Bender: New Providence, NJ, USA, 2010.

49. Hyatt, W.S. Hyatt \& Stubblefield, P.C., Atlanta, GA, USA. Personal Communication, 2009.

50. Restatement of the Law. Property 3d: Servitudes; American Law Institute Publishers: St. Paul, MN, USA, 2000.

51. Fennell, L. Contracting Communities. U. Ill. L. Rev. 2004, 2004, 829-898.

52. Restatement of the Law, Property, Servitudes: As Adopted and Promulgated by the American Law Institute at Washington, DC, May 12, 1998; American Law Institute Publishers: St. Paul, MN, USA, 2000.

53. Benson v. State. In North Western 2d; South Dakota Supreme Court: SD, USA, 2006; Volume 710 , p. 131. 
54. Nebraska Game and Parks Comission Regulations Title 163. In Nebraska Administrative Code; State of Nebraska: Lincoln, NE, USA, 2009.

55. Ranching for Wildlife; Available online: http://wildlife.state.co.us/Hunting/BigGame/ RanchingforWildlife/ (accessed on 31 May 2010).

56. Voluntary Public Access and Habitat Incentive Program interim rule. Federal Register, 2010, 75, 39135-39143.

57. Hunting Licenses and Permits; Available online: http://www.tpwd.state.tx.us/publications/ annual/general/hunt_licenses/ (accessed on 31 May 2010).

58. Airey, S.B. Conservation Easements in Private Practice. Real Property Trust Estate Law J. 2010, $44,745-822$.

59. Lindstrom, C. Income tax aspects of conservation easements. Wyo. L. Rev. 2005, 5, 1-57.

60. Lindstrom, C. Guide to the tax aspects of conservation easement contributions. Wyo. L. Rev. 2007, 7, 441-546.

61. Conservation and Preservation Easements act. In Nebraska Revised Statutes; State of Nebraska: Lincoln, NE, USA, 2010; Volume 4A, Section 76-2,111.

62. Cooperative Conservation Partnership Initiative; Available online: http://www.nrcs.usda.gov/ programs/ccpi/ (accessed on 17 March 2010).

63. Cooperative Conservation Partnership Initiative notice of request for proposals. Federal Register, 2010, 75, 18472-18482.

64. Langholz, J.; Lassoie, J.; Schelhas, J. Incentives for biological conservation: Costa Rica's private wildlife refuge program. Conserv. Biol. 2000, 14, 1735-1743.

(C) 2010 by the authors; licensee MDPI, Basel, Switzerland. This article is an Open Access article distributed under the terms and conditions of the Creative Commons Attribution license (http://creativecommons.org/licenses/by/3.0/). 